\title{
THE POTENTIAL EFFICACY OF AN AVIATION BIOTERRORIST ATTACK AND ITS PSYCHOSOCIAL CONSEQUENCES
}

\author{
Olaf E. TRUSZCZYŃSKI' ${ }^{1}$, Łukasz MACANDER², Marian MACANDER ${ }^{3}$ \\ ${ }^{1}$ Cardinal Stefan Wyszynski University in Warsaw, Warsaw, Poland \\ ${ }^{2}$ Polish Society for Future Studies, Warsaw, Poland \\ ${ }^{3}$ Military Institute of Aviation Medicine, Warsaw, Poland
}

Source of support: Own sources

Author's address: O. E. Truszczyński, Cardinal Stefan Wyszynski University in Warsaw, Dewajtis 5 Street, 01-815 Warsaw, Poland, e-mail: olaf1960@wp.pl

Abstract: The work concerns the analysis of the possibility of a bioterrorist attack using infected material using modern air transport carriers to infect the human population. It is possible to use passenger and transport planes, but the use of drones and minidrones seems the most dangerous. A bioterrorist attack is very specific and differs from other forms of terrorism, first of all in the possibility of self-replication of the pathogen, as well as the ability to "sleep" its operation even for many years and completely unexpectedly activate it. In such conditions, not only fast medical neutralizing action becomes crucial, but also calming psychosocial reactions and reasonable cooperation of the authorities and the media.

Keywords: air bioterrorism, aircraft as a weapon, drones attack, infected passengers, psychosocial reaction, unexplained psychosomatic symptoms, post traumatic stress disorder (PTSD)

Tables: 1 - References: 49 - Full-text PDF: http://www.pjambp.com • Copyright (C) 2017 Polish Aviation Medicine Society, ul. Krasińskiego 54/56, 01-755 Warsaw, license WIML • Indexation: Index Copernicus, Polish Ministry of Science and Higher Education 


\section{INTRODUCTION}

The fast development of a genetic engineering has meant that should led to the serious consideration and political talks should be given mostly to because of the possibility of transforming biological viruses into lethal leathal weapons, whose deliberate proliferation may lead to pandemic and deadly threat to the entire social groups. Conventional weapons produce immediate effects and have a direct impact on human health, while biological agents have prolonged consequences and will build future threats that can not be easily estimated [34]. Health consequences caused by biological diseases such as smallpox, increases the potential risk of transmission from person to person, which is a great specification of a biological weapon. Most biological agents suitable for a terrorist attack are odorless and invisible to humans [42]. In this case, the treatment procedures caused by infections are not sufficiently effective and there is a risk of developing a disease after being exposed to the infection. An attack with the use of a biological weapons seems nowadays a quite likely alternative to the terrorist "conventional" methods used so far [12]. With the help of relatively small means, very spectacular effects can be achieved leading to the death or severe diseases of many people. In addition, the consequences will not be limited only to direct victims, because there are reasonable assumptions that they will also cause serious perturbations of a psychological, sociological, economical and political nature and what worse intensifies social anxiety and individual concern. Differences in a relation to the others methods of a terrorism (such as aircraft hijacking or bomb attack) are so important that it should be assumed that there will also be fundamentally different human reactions, primarily related to the difficulty of determining the true nature of the damaging factor, the possibility of its impact in the short and long perspective [18]. The Aum Shinrikyo's 1995 sarin attack on the Tokyo metro station had reminded the world that by using a very simple method it can destroy the efforts of maintaining peace. The World Trade Center towers cataclysm on September 11th 2001 immediately was followed by a bioterrorist attack. These attacks were calculated to involve maximal psychological casualties, involving uncertainty, fear, social distortion and the economic crises and international disturbances [49].

\section{History of bioterrorism}

In the long history of human conflicts different biological substances and the expert knowledge about infectious diseases were used not only for healing, but also for killing other people. The history of the use of a biological weapons has a centuries-old tradition. A couple of examples:

- in the sixth century $B C$, the Assyrians poisoned wells useding ergot rye to poison enemies wells [13],

- the Romans used poisoned arrows by, submerging them into dead bodies or animal excrements [3],

- the Tatars catapulted the dead bodies to the opponent's side. This attack forced Feodosia inhabitants to, as a result of which the inhabitants of Feodosia were forced to leave the city and escaped Genoa and Venice. In this way, the epidemic has been expanded [15],

- apparently, also Polish troops in 1650 used missiles contaminated by the saliva of rabid dogs [15],

- in 1797, the Napoleonic army flooded the plains around Mantua (Italy) to strengthen the spread of malaria among the enemy [15],

- in 1863, the Confederates handed over clothes from patients with yellow fever and smallpox soldiers to the Union Forces during the American Civil War [3].

Those examples were fierce and terrifying but were used on the small scale. The possibility of using a biological agent as a weapon of mass destruction is much worse and threatening, especially in the last century and now. However, it was only the twentieth and twenty-first century that posed a threat in the form of making biological weapons of mass destruction a biological agent. During World War I, the German soldiers tried to infect horses and mules with sugar cubes contaminated with anthrax bacteria contained in sugar cubes horses and mules [37]. World War II was also the arena where biological weapons were tested. Japan created a wax unit called Unit 731, located in Beiyinhe in Manchuria and carried out experiments with prisoners of war [1]. Christopher, Cieslak, Pavlin, Eitzen [8] reported that several thousand prisoners died as a result of their experiments. What's more, mortality among people living in the area of unit 731 was very high for the next few years. After the war in 1950, the Americans carried out an experiment to infect human populations around the Bay of San Francisco with the bacteria Serratia marcescens, a low-risk pathogen that infects the skin and the respiratory system. However, the effect was quite exceptional, because almost the entire population was infected and despite seemingly harmless operation, 
several people were killed [9]. In the seventies of the XX century in the USSR research on biological weapons was conducted intensively. conducted. Pathogens such as tularemia, anthrax, glanders, chickenpox and encephalitis virus have been produced. In Sverdlovsk in 1979, as an effect of an accident, anthrax has penetrated laboratory walls. The epidemic occurred at a distance of $4 \mathrm{~km}$ from the research laboratory [1]. However, Soviet officials said it happened after eating contaminated meat, and it was not until 1992 that President Boris Yeltsin officially admitted that the epidemic was due to the waxy fault of these investigations experiments. This caused an anthrax epidemic that resulted in 77 morbidity and 66 deaths occurred within 28 days of the pathogen's release [29]. At present, we still do not exactly know what happened to the biological weapons stock in Russia.

\section{Definition of terrorism and bioterrorism}

Since attack on the World Trade Center in September 11th 2001, train bombings in London in March 11th 2004 and July 7th 2005 the term "the psychology of terror" increased it interest. All this resulted not only in fatalities and injuries of many people but also in the traumatic reactions of the whole societies. Crenshaw [11] believes that it is possible to talk about a new kind of terrorism which aims to transform the world based on primarily religious differences but also on a civilization and cultural changes. In this context the phrase global "strategy against terrorism" forced us to deal with global terrorism as opposition to the "old" terrorism which has a rather limited range and seek to obtain political support for their ideas. Above mentioned September 11th 2001 has became as a starting point for modern societies to prepare and planning a possible reaction to the use of a chemical, biological, radiological and, nuclear, (CBRN) weapons of mass destruction [44].

Defining terrorism is not only a theoretical issue but an operational necessity. Without answering the question of "what is terrorism" you can neither impose the responsibility on those countries that support terrorism or engage in state terrorism, nor can you take steps to combat terrorist organizations and their allies. Until now it had been built much more than 100 definitions of terrorism [27]. This proves that still not all aspects of this phenomenon are clear and comprehended.

The USA for example defined terrorism in accordance with the Federal Criminal Code, which defines terrorism as a means involving violent (...) or life-threatening activities [...] that violate the criminal law of the United States or any country and appears to be intended (i) to intimidate or coerce a civilian population; (ii) influence government policy through intimidation or coercion; or (iii) influence government behavior as a result of mass annihilation, homicide or kidnapping; and ... (C) occur primarily within the territorial jurisdiction of the United States ... " [46].

The definition of terrorism defined by Department of Defense (DOD) it is as "the unlawful use of violence or threat of violence to instill fear and coerce governments or societies. Terrorism is often motivated by religious, political, or other ideological beliefs and committed in the pursuit of goals that are usually political [22]. It should be noted that both of these deficits draw attention to the phenomenon of intimidation and the spread of fear throughout society or the terrorist act itself or only its announcement. Another definition concerning biological agents "The intentional release of an infectious particle such as a virus or a bacterium from the confines of a laboratory or medical practice must be formally condemned as an irresponsible threat against the whole human community" [26]. In this context bioterrorism can be defined as the intentional use of living organisms such as bacteria, viruses and fungi with the intent to cause disease, death, or environmental damage [5]. These agents are typically found in nature but it is possible that they could be changed to increase their ability to cause disease, make them resistant to current medicines or to increase their ability to be spread into the environment. Biological agents can be spread through the air, water or in the food. Bioterrorism has a potential and lethal method to threaten human individually or even nationwidenational wide. This intimidation may concern an unknown range of destructive influences of the pathogen on the human body and / or the threat of incurring attacks.

\section{Differences between bioterrorism and other forms of terrorism}

Infectious agents used in bioterrorist attacks have three features that make it very attractive in the hands of terrorists:

1. The pathogens replicate themselves, which means no more than they can reproduce and spread in the environment themselves [39].

2. Pathogens spread through people's contact with each other, making completely innocent people unwittingly "cooperate" with terrorists and become carriers of a lethal disease [39].

3. Dormant biological agents can go unnoticed for many years in the environment and appear unexpectedly [17]. 
The most important factor that differentiates bioterrorism from other forms of terrorism is that biological agents can be easily transferred from person to person. This means that far-reaching consequences are not easy to predict and can be much more harmful if you only consider an attack limited to one specific location. Bioterrorism is different from other types of terrorist methods, primarily a long-term impact on the population. The cruelty of biological weapons is based on uncertainty and the lack of clear targets, which causes difficulties in determining whether an attack has occurred and what its real extent is [20]. The worst case scenario that could be met in a bioterrorist attack is based on the assumption that you can unknowingly be the target of infection and later the carrier of an infectious substance. Biological weapons are therefore more fearsome terrorist than conventional war weapons, because there it is not only an intention tended to destroy a part of the population, but also used as a means to an end used to obtain a psychological impact on a much wider population - by introducing social anxieties, fear and violence. Human reactions can have a negative effect on others. One possible symptom is the possibility of panic behavior on a large scale. In such circumstances, lack of information and uncertainty about the psychological effects of bioterrorism complicate the task of a responsible preparation and proper response in the event of an attack. Clear understanding of how to deal with the psychological effects of a bioterrorism is crucial to the development and implementation of a realistic preventions [2]. At the same time, it is important to consider how to implement and communicate the plans to reduce anxiety and fear of the threat. This means that the same attack method and similar level of threat can cause significant health differences in affected populations depending on communication aspects, strategy

Tab. 1. Distinctions Between Terrorism and Bioterrorism [43].

\begin{tabular}{ccc}
\hline Name & Terrorism & Bioterrorism \\
\hline $\begin{array}{c}\text { Speed at which attack } \\
\text { results in effect }\end{array}$ & Immediate & Delayed or Prolonged \\
\hline Site of attack & Specific & Unknown \\
\hline $\begin{array}{c}\text { Knowledge of attack } \\
\text { boundaries/scope }\end{array}$ & Well understood & Unknown \\
\hline First responders & Police, fire, EMS & $\begin{array}{c}\text { Physicians, nurses, } \\
\text { public, health officials }\end{array}$ \\
\hline $\begin{array}{c}\text { Distribution of affected } \\
\text { patients }\end{array}$ & Concentrated area & $\begin{array}{c}\text { Geographically } \\
\text { dispersed }\end{array}$ \\
\hline $\begin{array}{c}\text { Decontamination od victims } \\
\text { and environment }\end{array}$ & $\begin{array}{c}\text { Confined } \\
\text { environment }\end{array}$ & $\begin{array}{c}\text { Geographically } \\
\text { dispersed }\end{array}$ \\
\hline Isolation/Quarantine & $\begin{array}{c}\text { Not usually } \\
\text { necessary }\end{array}$ & $\begin{array}{c}\text { Required for } \\
\text { transmissible diseases }\end{array}$ \\
\hline Medical interventions & Trauma, first aid & Antibiotics, vaccines \\
\hline
\end{tabular}

formulation, organizational issues and individual leaders' abilities.

\section{The case study of bioterrorism and human psychosocial reaction}

The act of bioterrorism prepared against the US postal system took place on Tuesday, 18 September 2001. It consisted on sending five letters that contained the anthrax spores (Bacillus anthracis). The attacks were named by the Federal Bureau of Investigation as Amerithrax [4] and occurred just a week after the September 11 attacks. Letters containing anthrax were sent to media offices and to two Democratic US Senators. As a result of this attack, the activities of the US Congress and the Supreme Court were suspended, as were postal operations covering the whole country. Eighteen out of twenty-three infected men survived, unfortunately, despite the treatment, five died. Over 33,000 have been subjected to prophylactic treatment. The total cost of expenses related to the neutralization of the impact of this attack is estimated at over USD 6 billion USD [40]. So the consequences were absolutely disproportionate to the costs incurred by terrorists. After this attack, the US Congress decided on a new legal regulation. This was set by the executive order of the White House Home Security Bureau on October 8, 2001. It defines the role of a new office in response to bioterrorism involving the coordination of:

1. Development of monitoring protocols and equipment for a use in detecting releases of biological, chemical and radiological threats.

2. Efforts to ensure public health readiness for a terrorist attack, including reviewing the vaccination policy and reviewing the adequacy and, if necessary, increasing the supply of vaccines and pharmaceuticals and hospital potential.

3. Increase efforts to prevent unauthorized access to development and unlawful import of chemical, biological, radiological, nuclear, explosive or other similar materials that could potentially be used in terrorist attacks in the United States.

4. Retention and disposal of biological, chemical, radiological, explosive or other hazardous materials in the event of a terrorist attack or attack involving such threats and coordination of efforts to mitigate the effects of such an attack [16].

U.S. Postal Service has become a place of chaos and confusion, which had wide social, behavioral, psychological and organizational consequences. They affected both local communities and the whole nation. Although the purpose of bioterrorism was focused on specific people, it was at this 
time that receiving letters or parcels became dangerous or at least very unpleasant. The US government and public health organizations were not prepared to counteract both biological effects and mental health problems. Today, however, it is known that awareness, understanding, planning, preparation and perhaps the most important practical exercises are crucial for the proper response of society to terrorism and have far-reaching consequences for effective coping with bioterrorist action. Bioterrorism raises special safety rules and restrictions such as manage and secure vaccination programs, ensure limited access to the prophylactic medications, possible evacuation of affected people and place assignment for isolation. From psychological point of view establishing and training professional management could reduce the size of the attack [19]. This requires not only preparation, but must also influence media activities, ensuring adequate communication of risks, public education programs and leadership, to maintain public confidence and ensure that people follow the guidelines indicated by these measures in the event of the spread of such disease.

Bioterrorist acts can be targeted at any number of goals such as achieving a political goal, making revenge, punishing unbelievers or shaping an apocalyptic vision. Victims who have been killed, wounded or even directly affected are rarely the main target. It is, however, fear and fear installed in the on society for as long as possible, the loss of a sense of personal and community security and disruption of critical social infrastructure that can shake down maim the economy and leadership of the nation. Immediately after the terrorist attack on the US postal system, people reacted unsuccessfully because they did not receive any reliable information from leaders or made decisions based on fear causing unhelpful behavior and even panic. Biological weapons are expected to bring not only death and negative consequences to the biologically healthy infected people, but also a psychological and psychosomatic symptoms such as prolonged anxiety attacks, including nausea, fever and headaches, long-term malaise. In addition, psychosocial distrust is to spread not only towards the government and medical staff, but also in relation to people from the neighborhood [33]. In above all the aim of a bioterrorism is breaking the public trust in administrations and public institutions. It is also to prove that deliberate damage is easy and possible at any time, and the government, politicians and local leaders are not able to prevent fatal consequences. Bioterrorism is a special type of man-made disaster that causes a much larger percentage of psychological victims than natural accidents or technological accidents [20]. There will be traumatic disorders such as unexplained somatic symptoms, depression, emotional outbursts, anxiety disorders, increased alcohol consumption and addictive substances [10]. The act of a bioterrorism requires not only the segregation of medical victims, but above all an effective risk assessment related to the possibility of panic behavior [38]. Issues related to panic include a psychological mechanism that narrows down human thinking to a selfish form of action. There is a belief that there are no other ways to escape this situation. Although there are not many examples of panic reactions after a catastrophe, it is still possible to take into the account among the risk factors of panic. Norris, Friedman, Watson [31] conducted a review of epidemiological literature investigating 160 samples of disaster victims published since 1981 on the psychological effects of a natural and man-made disasters on more than 60,000 people. As with other types of disasters, an attacker-terrorist will lead to mental disorders and psychiatric diseases. One of the specific threats is the possibility of being a witness to the death of a family member or close relatives, which may cause symptoms of PTSD, depression, who were susceptible to an attack before the event or are already suffering from the disease. Example of in clinical trials of victims of the attack in Oklahoma City stated by. North, Pfefferbaum, Kawasaki, Lee, Spitznagel [32] for example found that 34\% victims had PTSD and 22\% a severe depression.

\section{Aviation bioterrorism}

Every year, around 4 billion passengers travel by air [21]. This huge mass of people can also pose as a very serious threat to the risk of transmitting infectious diseases. This can happen accidentally by a single contact with an infected passenger or even worse, deliberately. The intention of conscious contagion of passengers, carried out in a closed cabin of aircraft, as well as other people after leaving the aircraft by the patient, is a pure act of the bioterror. Due to the fact that various infections can be easily transferred from person to person, but in a well-ventilated room, can limit the risk of disease transmission is limited to two rows of seats adjacent to the infected person. Unfortunately it is difficult to assess the effectiveness of such action. Medical data indicate that such cases are rare and have never led to an outbreak [28]. However, due to the long-term effects of transmission of infectious diseases from one continent to another, this risk can not be exclud- 
ed [47]. Currently, there is no effective method of eliminating this type of suicide passengers to prevent them from entering a public space, such as an airplane and an airport, because, inter alia, the period of incubation of an infectious disease may be asymptomatic, so no one will notice it. There are two important elements that can be used in terrorist tactics: an airplane treated as a weapon and a human being as a carrier of biological agents. In this way, it is possible to write scenarios describing the possible course of such an event. An example of a virus that can be taken into account in such a scenario is, for example, smallpox, because the incubation period is about 2 weeks and is easily transmitted between people. Another may be a virus that causes symptoms of acute respiratory failure (SARS). Terrorist operations using these types of pathogens can have very uncertain consequences, among others because the extent of infection is unknown due to the high unpredictability of the spread of the disease. These properties are therefore ideal for terrorists, because they cause anxiety and a sense of overwhelming danger that can not be controlled and thus controlled and ultimately lead to organizational information chaos [30]. In such conditions, opposite concepts of solving the problem are created. Bioterrorist attacks are often followed by the pattern of transferring "bad things" by "bad people". Paradoxically, pilots and passengers are thoroughly checked at airports, but transport of goods, especially on domestic lines, is subject to much less restrictions. It can be a way to carry pathogens. Another risk is the possibility of spraying biological agents from the plane's deck. It can also be sprayed over large urban agglomerations and drinking water reservoirs. Due to the relatively small amount of aerosol and the potentially large number of infected people, this method seems relatively easy to use. Aerosols for infection are odorless and tasteless, invisible and very cheap compared to other types of weapons of mass destruction. The carrier of such an aerosol can be an airplane, a helicopter, and perhaps primarily an unmanned aircraft or a small drone, because in this case there is no risk of catching terrorists involved in such an operation. The use of the aircraft for a large-scale biological attack is a completely real scenario, which unfortunately can be fulfilled. There is also a separate type of terrorism called agroterrorism but one can also distinguish its subgroup of aviation agroterrorism, consisting in the use of an airplane to try to spread germs in agricultural areas. The purpose of this action is to poison large areas, farm animals and pathogenic pathogens against livestock and agricultural crops so as to cause food poisoning in order to change people's social and eating habits for humans and forcing change in eating and social habits [14]. This will trigger numerous social tensions. The big problem is the lack of protection of agricultural areas against such an attack. The transport of biological pathogens can be linked to an advanced drug transfer methods. For example, there were many cases of drug trafficking using a drone. An attack of microdrons may also be considered, which can be completely undetectable or detectable to a minimum, although the amount of transmitted infectious agent would also be small in this case. In this context, it should be noted that air is the most suitable environment for transporting biological agents. It seems in this situation that the basic difficulty of bioterrorists is not the transfer of a biological factors, but their production [23].

\section{SUMMARY AND CONCLUSION}

The characteristic use of a biological agents often means deferring the reaction of the human body for an indefinite time depending on the factor used and its real impact. Lederberg [25] thinks that the vulnerability of the US to bioterrorist attacks is high, and the threat "is probably the most onerous and the most serious security challenge we face." In bioterrorist activities, the threat is not anthrax, but an overwhelming fear of possible, allencompassing consequences. To an American outpost, five people have been infected with anthrax, thousands have been tested, and millions have feared for their lives. Uncertainty about future acts of a bioterrorism is extremely painful, involves an unpredictable range of activities that nobody has experienced before, so there is anxiety that Butterworth calls "anticipation of fear" [6]. In the psychology of terrorism, it is important to inform the public that this method of destabilizing social life is more related to subjective perception (also of a collective nature) than to reality. To win this war, people cannot succumb to the propaganda of terrorists strengthened by free media, give faith to rumors or, unexpected information and analysis of the so-called "specialists". However, it should be noted that in order to meet these challenges, a high level of social trust is needed not only for the government, but also for political opponents and scientific authorities who should represent a unified, rational and balanced message. Society should also be informed about facts, because concealing the truth leads to conspiracy theories, dissemination of untested impressions. The main dis- 
tinguishing feature of a biological weapons is that even a small amount of pathogen can be enough to contribute to the death or serious illness of many people. The period of full development of the destructive force is not immediate; therefore it is extremely difficult to prepare activities in terms of readiness, protection and response. There is still a gap in knowledge and scientific analyzes regarding the psychological effects of bioterrorism and ways to protect people from the devastating consequences of such a catastrophe. Examples of other events, such as natural epidemics and accidents, are a kind of background.

The history of previous experiences includes tips on the preparation and plans of bioterrorism involving public organizations. These experiences emphasize the individual psychological weight of a risk perception and decisions regarding the preparation of medical assessment in the event of a biological attack [35]. The medical healthcare system must be prepared for the management of a bioterrorist event. These experiences emphasize the possibility that medical facilities may be overwhelmed by the needs of people who have been severely or potentially affected. Wessely, Hyams, Bartholomew [48] described psychosocial diseases in connection with 9/11 September, 2001 at a school in Washington, where bioterrorist rumors developed an anxiety reaction of 16 students and one teacher, hospitalization was necessary for psychological reasons, although from a medical point of view they were not in danger [41]. What is needed to develop an effective program to counteract the possibility of a bioterrorist attack is primarily a modern system for detecting the threat of biological contamination, as well as methods for detecting drones, including minidrons [7]. Both tasks seem difficult to implement, but are necessary in the context of building effective firewalls. Secondly, it is necessary to create scenarios for a possible coping with epidemics, but also for psychosocial reactions in response to these threats [36]. Hyams et al. [20] argue that as a result of the experience gained from the World Trade Center attack on September 11, 2001 and the subsequent mailing of anthrax in October 2001, four long-term health consequences should be seriously considered: (1) chronic injuries and pathogen-induced diseases; (2) issues related to possible infertility of infected people (3) psychological effects; and (4) an increased level of unexplained psychosomatic symptoms. So two of the four symptoms concern psychological problems, these issues still seem underestimated both by government agencies and the society itself.

\section{AUTHORS' DECLARATION:}

Study Design: Olaf E. Truszczyński, Łukasz Macander, Marian Macander; Data Collection: Olaf E. Truszczyński, Łukasz Macander, Marian Macander; Manuscript Preparation: Olaf E. Truszczyński, Łukasz Macander, Marian Macander; Funds Collection: Olaf E. Truszczyński, Łukasz Macander, Marian Macander. The Authors declare that there is no conflict of interest.

\section{REFERENCES}

1. Al-Agamy MHM. Tools of Biological Warfare. Research Journal of Microbiology. 2011; 6:193-245.

2. Ashford DA, Kaiser RM, Bales ME, Shutt K, Patrawalla A, McShan A, Tappero JW, Perkins B, Dannenberg AL. Planning against biological terrorism: lessons from outbreak investigations. Emerging Infectious Diseases. 2003; 9(5):515-519.

3. Barras V, Greub G. History of biological warfare and bioterrorism. Clin Microbiol Infect. 2014; 20(6):497-502. doi: 10.1111/1469-0691.12706.

4. Blendon RJ, Benson JM, DesRoches CM, Pollard WE, Parvanta C, Hermann MJ. The impact of anthrax attacks on the American public. Medscape General Medicine. 2002; 4(2):1. doi: 10.1089=bsp.2009.0059G.

5. BusI KM, Bleck TP. Treatment of neuroterrorism. Neurotherapeutics. 2012; 9(1):139-157. doi: 10.1007/s13311-011-0097-2.

6. Butterworth R. (2002). https://www.cbsnews.com/news/the-psychology-of-bioterrorism-how-to-fight-back/.

7. CBRNE (2017). Terrorism newsletter. ISIS Teaching US MilitarySome New Drone Development. source http://i-hls. com/2017/03/isis-teaching-u-s-military-new-drone-developments/.

8. Christopher GW, Cieślak TJ, Pavlin JA, Eitzen EM. Biological warfare: a historical perspective. JAMA. 1997; 278:412-417.

9. Cole LA. Clouds of Secrecy: The Army's Germ-Warfare Tests Over Populated Areas. (Foreword by Alan Cranston). Totowa, New Jersey: Rowman \& Littlefield 1988. 
10. Cole LA, Connell N. Local Planning for Terror and Disaster: From Bioterrorism to Earthquakes. Pub. Date: 8/6/2012 Publisher: Wiley, John \& Sons 2013.

11. Crenshaw M. The Psychology of Terrorism: An Agenda for the 21st Century. Political Psychology. 2000; 21(2):405-420.

12. Danzig R. Proliferation of biological weapons into terrorist hands, in: Campbell KM, Nye JS, Scowcroft B. (ed). The Challenge of Proliferation a Report of the Aspen Strategy Group. The Aspen Institute. 2005:65-81.

13. Etzel RA. Mycotoxins. JAMA. 2002; 287(4):425-7.

14. Forest JJF. Framework for Analyzing the Future Threat of WMD Terrorism. Journal of Strategic Security. 2012; 5(4):51-68. doi: 10.5038/1944-0472.5.4.4.

15. Frischknecht F. The history of biological warfare. EMBO Reports. 2003; 4(1):47-52. doi: 10.1038/sj.embor.embor849.

16. Gellman B. Struggles Inside the Government Defined Campaign. Washington Post, 2001.

17. Hall MJ, Norwood AE, Ursano RJ, Fullerton CS, Levinson CJ. Psychological and behavioral impacts of bioterrorism. PTSD Research Quarterly. 2002; 13(4):1-7.

18. Holgersson A. Preparedness for mass-casualty attacks on public transportation. Umeå University, Faculty of Medicine, Department of Surgical and Perioperative Sciences, Surgery. 2016, 64.

19. Hupert N, Chege W, Bearman GML, Pelzman FN. Antibiotics for anthrax; patient requests and physician prescribing practices during the 2001 New York City attacks. Arch Intern Med. 2004; 164(18):2012-2016.

20. Hyams KC, Murphy FM, Wessely S. Responding to chemical, biological or nuclear terrorism: the indirect and long-term health effects may present the greatest challenge. J Health Polit Policy Law. 2002; 27(2):273-291.

21. IATA (2017). http://www.iata.org/pressroom/pr/Pages/-10-24-01.aspx.

22. Joint Publication 3-07.2. (2010). Antiterrorism. http://www.bits.de/NRANEU/others/jp-doctrine/JP3_07.2\%2810\%29.pdf.

23. Kreps S. What Everyone Needs To Know. Oxford, New York: Oxford University Press. 2016.

24. Lamb A. Biological weapons: the facts not the fiction. Clin. Med. 2001; 1:502-504. doi:10.7861/clinmedicine.1-6-502.

25. Lederberg J. Biological Warfare. Emerging Infectious Diseases. 2001; 7(6):1070-1071. doi: 10.3201/eid0706.010636.

26. Lederberg JE. Epilogue. in Lederberg, J., ed., Biological weapons: limiting the threat. Cambridge, Mass., MIT Press. 1999; 95-111.

27. Levitt G. (1986) Is Terrorism Worth Defining? Ohio Northern University Law Review. 1986; 13:97.

28. Mangili A, Gendreau M. Transmission of infectious diseases during commercial air travel. Lancet. 2005; 365:989-996.

29. Meselson M, Guillemin J, Hugh-Jones M, Langmuir A, Popova I, Shelokov A, Yampolskaya O. The Sverdlovsk anthrax outbreak of 1979. Science. 1994; 266(5188):1202-1208.

30. Mueller J. Simplicity and Spook: Terrorism and the Dynamics of Threat Exaggeration. International Studies Perspectives. 2005; 6(2):222.

31. Norris FH, Friedman MJ, Watson PJ. 60,000 disaster victims speak: Part II. Summary and implications of the disaster mental health research. Psychiatry. 2002; 65(3):240-260.

32. North CS, Pfefferbaum B, Kawasaki A, Lee S, Spitznagel EL. Psychosocial adjustment of directly exposed survivors seven years after the Oklahoma City bombing. Comprehensive Psychiatry. 2011; 52(1):1-8. doi: 10.1016/j.comppsych.2010.04.003.

33. Page LA, Petrie KJ, Wessely S. (2006). Psychosocial responses to environmental incidents: a review and a proposed typology. J Psychosom Res. 2006; 60(4):413-422.

34. Pal M, Tsegaye M, Girzaw F, Bedada H, Godishala V, Kandi V. An Overview on Biological Weapons and Bioterrorism. American Journal of Biomedical Research. 2017; 5(2):24-34.

35. Pollard WE. Public perceptions of information sources concerning bioterrorism before and after anthrax attacks: an analysis of national survey data. J Health Commun. 2003; 8:93-103. doi: 10.1080/10810730305704.

36. Post JM. Terrorist Psycho-logic: Terrorist behavior as a product of psychological forces. In W. Reich (ed.), Origins of Terrorism: Psychologies, ideologies, theologies, states of mind. Cambridge: Cambridge University Press. 1990; 25-40.

37. Redmond C, Pearce MJ, Manchee RJ, Berdal BP. Deadly relic of the Great War. Nature. 1998; 393:747-748.

38. Reich W. Understanding terrorist behavior: The limits and opportunities of psychological inquiry. In W. Reich (ed.), Origins of terrorism: Psychologies, ideologies, theologies, states of mind. Cambridge: Cambridge University Press. $1990 ; 261-279$.

39. Richards E, O’Brien T, Rathbun K. Bioterrorism and the Use of Fear in Public Health. The Urban Lawyer. 2002; 34(3):685-726.

40. Ryan E. Creating a Secure Network: The 2001 Anthrax Attacks and the Transformation of Postal Security. 2014; 62(1):161182. 
Truszczyński O. E. et al. - The potential efficacy...

41. Shaffer D, Armstrong G, Higgins K, Honig P, Coyne P, Boxwell D, Beitz J, Leissa B, Murphy DI. Increased US prescription trends associated with the CDC Bacillus anthracis antimicrobial postexposure prophylaxis campaign. Pharmacoepidemiol Drug Saf. 2003; 12(3):177-182.

42. Shultz JM, Espinel Z, Galea S, Shaw JA, Miller GT. Surge, sort, support: disaster behavioral health for health care professionals. University of Miami Center for Disaster and Extreme Event Preparedness: Disaster Life Support Publishing 2006.

43. Stein BD, Tanielian TL, Eisenman DP, Keyser DJ, Burnam MA, Pincus HA. Emotional and Behavioral Consequences of Bioterrorism: Planning a Public Health Response. The Milbank Quarterly. 2004; 82(3):413-455.

44. Stone FP. The „Worried Well”. Response to CBRN Events: Analysis and Solutions. The Counterproliferation Papers No. 40 USAF Counterproliferation Center. Air University Maxwell Air Force Base. Alabama 2007. https://fas.org/irp/threat/cbw/ worried.pdf.

45. Ursano R. Workplace preparedness for terrorism: report of findings to Alfred P. Sloan Foundation. Center for the Study of Traumatic Stress, Uniformed Services University School of Medicine 2011. http://www.usuhs.mil/psy/SloanReport.html.

46. Weigend T. The Universal Terrorist: The International Community Grappling with a Definition Journal of International Criminal Justice. 2006; 4(5):912-932. doi: 10.1093/jicj/mql063.

47. Weller RE. Risk of disease spread through bioterrorism. 2006; 42(4):351-67.

48. Wessely S, Hyams KC, Bartholomew R. Psychological implications of chemical and biological weapons: Long term social and psychological effects may be worse than acute ones. British Medical Journal. 2001; 323(7318): 878-879.

49. Zanders JP. Assessing the Risk of Chemical and Biological Weapons Proliferation to Terrorists. The Nonproliferation Review. 1999; 6(4):17-34.

\section{ACKNOWLEDGEMENTS}

The views, opinions, and findings contained in this article are our own and should not be construed as an official Polish Air Force position, policy, or decision, unless so designated by other official documentation.

Cite this article as: Truszczyński O.E, Macander $Ł$, Macander M. The Potential Efficacy of an Aviation Bioterrorist Attack and Its Psychosocial Consequences. Pol J Aviat Med Bioeng Psychol 2017; 23(2): 19-27. DOI: 10.13174/pjambp.16. 07. 2018.03 